\title{
Intralipid as a novel Autophagy Inducer Target for Neurotoxic Effects of Rotenone
}

\author{
Eman A. Abdel-Razek ${ }^{1}$, Amal A. El-Bakary ${ }^{1}$, Sameera Sh. Hamed ${ }^{1}$, Sara El-desouky ${ }^{2}$, \\ Adel EL-Mansoury ${ }^{1}$
}

KEYWORDS

Metformin,

Intralipid,

Neurodegenerative diseases,

Rotenone,

Autophagy.

\begin{abstract}
Previous studies showed that augmentation of the autophagy-lysosome process may be beneficial for many neurodegenerative diseases including Parkinson's disease (PD), in which abnormal accumulation of aggregated proteins and mitochondrial dysfunctions are considered as crucial pathogenesis. Recently, several studies have advocated the neuroprotective effects of intralipid in models of numerous neurodegenerative diseases. In this study, seventy "C57BL/6" mice divided into seven groups were used to evaluate the neuroprotective effects of autophagy enhancement using metformin and intralipid through neurobehavioural, a histopathological and immunohistochemical examination of rotenone-exposed mice brain. The mice were administrated rotenone $(2.5 \mathrm{mg} / \mathrm{kg}$ intraperitoneally), metformin $(100 \mathrm{mg} / \mathrm{kg} / \mathrm{day}$ orally) and intralipid $20 \%(15$ $\mathrm{mL} / \mathrm{kg}$ intraperitoneal) daily for 4 weeks. Intralipid significantly recovered the damaged brain tissue and alleviated rotenone-induced brain damage. Furthermore, the co-administration of metformin and intralipid against rotenone produced more therapeutic efficiency. Intralipid exerted protection against rotenone-induced neuro-injuries to some extent through the autophagy process. The pharmacological induction of autophagy by intralipid may represent a novel therapeutic strategy as a disease-modifier in neurodegenerative diseases.
\end{abstract}

\section{Introduction}

Autophagy "self-eating", conserves cytoplasmic homeostasis through lysosomefacilitated self-digestion and reutilizing of protein aggregates and damaged organelles. However, autophagy may be dysregulated in some disorders as metabolic, infectious and neurodegenerative disorders (Netea-Maier et al., 2016).

Rotenone was used as both herbicide and insecticide. It was also mixed with other pesticides, such as pyrethrins and lindane in

\footnotetext{
(1) Forensic Medicine and Clinical Toxicology Department, Faculty of Medicine, Mansoura University, Mansoura, Egypt.

(2) Medical Experimental Research Center (MERC), Faculty of Medicine, Mansoura University, Mansoura, Egypt
}

products to control insects. It was a mitochondrial complex I inhibitor, inducing loss of dopaminergic (DA) neurons in substantia nigra pars compacta (SNpc) as well as augments oxidative stress (Hoffman et al., 2019).

Besides, it can suppress autophagic flux promoting the accumulation of autophagic vacuoles resulting in the accumulation of different mutant proteins, such as mutant $\alpha$ synuclein (causing Parkinson's disease) (Zheng et al., 2010; Hu et al., 2016).

According to our previous research (Abdelrazik et al., 2020) it was found that inhibition of autophagy plays a role in rotenone neurotoxicity. On this basis, we hypothesized that activation of autophagy 
may modulate the neurotoxic effects of rotenone.

Intravenous lipid emulsions (ILE) used in parenteral nutrition therapy has shown, through the "lipid sink" theory, to rapidly reverse the clinical toxicity induced by a variety of compounds (Eisenkraft and Falka, 2016).

As rotenone is highly lipophilic, exposed patients may benefit from this antidote therapy. To the best of our knowledge, there was no previous study regarding the consequence of intralipid treatment on neurotoxic effects of rotenone.

On the other hand, increasing autophagy in a variety of cell types was induced by metformin (a widely used anti-diabetic agent). This may have potential clinical therapeutic effects against neurodegenerative diseases (Rotermund et al., 2018).

This work aimed to evaluate the potential neuroprotective effects of lipid emulsions such as intralipids through activation of the autophagic process against the neurotoxic effects of rotenone.

\section{Material and methods:}

\section{Study design:}

Seventy C57 black 6 "C57BL/6" male mice (25-30 g. weight) were used in this study. Animals were kept under standard laboratory conditions with a 12-hour light/dark cycle and a room temperature of $22 \pm 2{ }^{\circ} \mathrm{C}$. The study was agreed upon by the Institutional Research Board (IRB), Faculty of Medicine, Mansoura University (Code number: MD/17.03.149). This experimental work was conducted in the Medical Experimental Research Centre, Faculty of Medicine, Mansoura University.

Mice were randomly divided into seven groups each contains 10 mice: Control group (2.5 $\mathrm{mL} / \mathrm{Kg}$ carboxymethyl cellulose $0.5 \%$ intraperitoneal), rotenone group (rotenone 2.5 $\mathrm{mg} / \mathrm{kg}$ intraperitoneal) (Javed et al., 2016), metformin group (metformin $100 \mathrm{mg} / \mathrm{kg} /$ day orally) (Cittadini et al., 2012), intralipid group $(15 \mathrm{~mL} / \mathrm{kg}$ intralipid $20 \%$ intraperitoneal)
(Dunn et al., 2012), rotenone plus metformin group (metformin was administered simultaneously with rotenone), rotenone plus intralipid group (intralipid was administered simultaneously with rotenone) and rotenone plus metformin plus intralipid group (intralipid and metformin were administered simultaneously with rotenone). Each animal in the seven groups was administered the test substance daily for 4 weeks.

Assessment of the neurotoxic effects of rotenone was done through neurobehavioural (locomotor) tests, histopathological and immunohistochemical examination of the brain dopaminergic system.

\section{Methods:}

1- Neurobehavioural (locomotor) tests (Ahmed et al., 2017):

The locomotor activity of the mice was evaluated at day 28 of the study by the use of ANY-box tests.

2- Histopathological evaluation (Hoffman et al., 2016):

At the end of the 4th week, under anesthesia brain tissues were rapidly dissected and fixed for 2 days with $10 \%$ paraformaldehyde. The brain sections were stained with hematoxylin-eosin. Substantia nigra pars compacta (SNpc) and corpus striatum were examined microscopically and photographed.

3- Immunohistochemical study (Hoffman et al., 2016):

Paraffin-embedded sections were deparaffinized and blocking of endogenous peroxidase using $30 \%$ hydrogen peroxide in methanol for 10 minutes and serum blocking solution $(10 \%$ non-immune serum) for 10 minutes was used. Antigen retrieval was done by the emersion of the slides in EDTA solution for 20 minutes at $90 \mathrm{o} C$ in a water bath.

a) Immunohistochemistry for the dopaminergic system:

Brain sections were incubated with primary mouse monoclonal anti tyrosine hydroxylase (TH) antibody. Tyrosine hydroxylase was found in the cytosol of cells 
containing catecholamines that can be depleted due to neuronal toxicity of dopaminergic neurons. So, it was selected to evaluate the neurodegenerative effects (Swarnkar et al., 2010). Anti-tyrosine hydroxylase antibody diluted (1: 1000) overnight at $4^{\circ} \mathrm{C}$. After several washes with PBS, sections were incubated with biotinylated secondary antibody (1: 500), for one hour at room temperature, dehydrated and covered.

b) Immunohistochemistry for Microtubule Associated Protein Light Chain 3 (LC3) positive cells (Mizushima et al., 2010): The LC3 positive cells expression was quantified to assess the degree of autophagy stimulation, as this protein was known to exist on autophagosomes and serves as a widely used marker for autophagosomes.

c) Computer-assisted digital image analysis (Digital morphometric study): Captured images were analyzed using Image $\mathrm{J}$ software version ij146-jdk6 for windows 7 (http://download.cnet.com/Image J-32bit/3000-21924- 7587 9102.html).

\section{Statistical analysis}

Data were analyzed using the computerized Statistical Package of Social Science (SPSS) program for Windows (Standard version 21).

\section{Results:}

Rotenone significantly increased the total distance traveled, numbers of line crossing, average speed, maximum speed and rotations of the animal's body. However, it significantly decreased the efficient path.

Both metformin and intralipid treatment significantly changed these effects. However, there was no statistically significant difference between metformin-treated groups and intralipid treated groups. Also, there was no statistically significant difference between both antidotes and combined metformin and intralipid treated groups except numbers of line crossing (Tables $1 \& 2$ and Figures $1 \&$ 2).

Table (1): Statistical analysis of neurobehavioral tests (total distance traveled $(\mathrm{m})$ and the number of line crossing) among studied groups ( $\mathrm{n}=70$ mice $)$.

\begin{tabular}{|c|c|c|c|c|c|c|c|c|c|c|}
\hline \multirow{2}{*}{\begin{tabular}{|l|} 
Studied \\
groups \\
$(\mathrm{n}=10 \quad$ mice \\
each)
\end{tabular}} & \multicolumn{5}{|c|}{ Total distance travelled (m) } & \multicolumn{5}{|c|}{ Number of line crossing } \\
\hline & $\begin{array}{c}\text { mean } \\
\pm \text { SEM }\end{array}$ & p1 & p2 & p3 & p4 & $\begin{array}{c}\text { mean } \\
\pm \text { SEM }\end{array}$ & p1 & p2 & p3 & p4 \\
\hline Control & $3.89 \pm 0.9$ & & & & & $18.26 \pm 4.02$ & & & & \\
\hline Rotenone & $8.05 \pm 2.36$ & $<0.001^{*}$ & & & & $49.32 \pm 17.35$ & $0.010^{*}$ & & & \\
\hline Metformin & $4.41 \pm 0.99$ & 0.152 & $<0.001 *$ & & & $19.50 \pm 3.92$ & 0.468 & $0.001 *$ & & \\
\hline Intralipid & $3.09 \pm 1.96$ & 0.474 & $<0.001^{*}$ & 0.128 & & $12.75 \pm 6.21$ & 0.108 & $0.001 *$ & 0.096 & \\
\hline $\begin{array}{l}\text { Metformin+ } \\
\text { Rotenone }\end{array}$ & $2.78 \pm 1.73$ & 0.264 & $<0.001 *$ & $0.048^{*}$ & 0.637 & $12.87 \pm 6.12$ & 0.126 & $0.001 *$ & 0.101 & 0.963 \\
\hline $\begin{array}{l}\text { Intralipid+ } \\
\text { Rotenone } \\
\end{array}$ & $2.74 \pm 1.01$ & 0.173 & $<0.001 *$ & $0.039 *$ & 0.668 & $12.62 \pm 5.52$ & 0.082 & $0.001 *$ & 0.074 & 0.959 \\
\hline $\begin{array}{l}\text { Metformin } \\
\text { +intralipid+ } \\
\text { rotenone }\end{array}$ & $2.73 \pm 0.65$ & 0.163 & $<0.001 *$ & $0.035^{*}$ & 0.659 & $7.25 \pm 1.49$ & $<0.005 *$ & $0.001 *$ & $0.001 *$ & 0.019 \\
\hline ANOVA test & \multicolumn{5}{|l|}{11.45} & \multicolumn{5}{|l|}{10.01} \\
\hline p-value & \multicolumn{5}{|l|}{$<0.001 *$} & \multicolumn{5}{|l|}{$<0.001^{*}$} \\
\hline
\end{tabular}

P-value: is for comparison between the groups assessed via ANOVA test, p1: on comparing control group with other groups, p2: on comparing rotenone group with other groups, p3: on comparing the metformin-treated group with other groups, p4: on comparing intralipid treated group with other groups, data expressed as mean \pm standard error of the mean $(\mathrm{SEM}),{ }^{*}$ significant at $\mathrm{p} \leq 0.05, \mathrm{n}$ : number, $\mathrm{m}$ : meter. 
Table (2): Statistical analysis of neurobehavioral tests (average speed $(\mathrm{m} / \mathrm{s})$ and maximum speed $(\mathrm{m} / \mathrm{s})$ among studied groups $(\mathrm{n}=70$ mice $)$.

\begin{tabular}{|c|c|c|c|c|c|c|c|c|c|c|}
\hline \multirow{2}{*}{$\begin{array}{c}\begin{array}{c}\text { Studied groups } \\
(\mathrm{n}=10 \text { mice } \\
\text { each })\end{array} \\
\end{array}$} & \multicolumn{5}{|c|}{ Average speed (m/s) } & \multicolumn{5}{|c|}{ Maximum speed $(\mathrm{m} / \mathrm{s})$} \\
\hline & $\begin{array}{c}\text { Median } \\
(\text { Min-Max) }\end{array}$ & p1 & p2 & p3 & p4 & $\begin{array}{c}\text { Median } \\
(\text { Min-Max) }\end{array}$ & p1 & p2 & p3 & p4 \\
\hline Control & $\begin{array}{c}0.03 \\
(0.02-0.04)\end{array}$ & & & & & $\begin{array}{c}0.20 \\
(0.13-0.30)\end{array}$ & & & & \\
\hline Rotenone & $\begin{array}{c}0.075 \\
(0.03-0.09)\end{array}$ & $0.006^{*}$ & & & & $\begin{array}{c}0.33 \\
(0.16-0.86)\end{array}$ & $0.012 *$ & & & \\
\hline Metformin & $\begin{array}{c}0.042 \\
(0.03-0.05)\end{array}$ & 0.171 & $0.011^{*}$ & & & $\begin{array}{c}0.22 \\
(0.02-0.28)\end{array}$ & 0.141 & $0.25^{*}$ & & \\
\hline Intralipid & $\begin{array}{c}0.024 \\
(0.01-0.05) \\
\end{array}$ & 0.370 & $0.005^{*}$ & 0.121 & & $\begin{array}{c}0.21 \\
(0.17-0.28) \\
\end{array}$ & 0.208 & $0.019^{*}$ & 0.961 & \\
\hline $\begin{array}{l}\text { Metformin+ } \\
\text { Rotenone }\end{array}$ & $\begin{array}{c}0.018 \\
(0.01-0.05)\end{array}$ & 0.170 & $0.001 *$ & 0.078 & 0.477 & $\begin{array}{c}0.18 \\
(0.15-0.21)\end{array}$ & 0.833 & $0.009^{*}$ & 0.548 & 0.688 \\
\hline $\begin{array}{l}\text { Intralipid+ } \\
\text { Rotenone }\end{array}$ & $\begin{array}{c}0.018 \\
(0.01-0.04)\end{array}$ & 0.188 & $0.001 *$ & 0.076 & 0.494 & $\begin{array}{c}0.19 \\
(0.16-0.23)\end{array}$ & 0.834 & $0.009^{*}$ & 0.141 & 0.829 \\
\hline $\begin{array}{l}\text { Metformin } \\
\text { +intralipid+ } \\
\text { rotenone }\end{array}$ & $\begin{array}{c}0.022 \\
(0.02-0.03)\end{array}$ & 0.351 & $0.003^{*}$ & 0.104 & 0.849 & $\begin{array}{c}0.17 \\
(0.15-0.36)\end{array}$ & 0.600 & 0.052 & 0.247 & 0.337 \\
\hline $\begin{array}{l}\text { Kruskil } \\
\text { wallis test }\end{array}$ & \multicolumn{5}{|l|}{18.13} & \multicolumn{5}{|l|}{18.284} \\
\hline p-value & \multicolumn{5}{|l|}{ 0.003* } & \multicolumn{5}{|l|}{ 0.003* } \\
\hline
\end{tabular}

P-value: is for comparison between the groups assessed according to Kruskal Wallis test, p1: on comparing control group with other groups, p2: on comparing rotenone group with other groups, p3: on comparing metformin and rotenone group with other groups, $\mathrm{p} 4$ : on comparing intralipid and rotenone group with other groups, data expressed as median $\{$ minimum $(\min )$-maximum $(\max )\},{ }^{*}$ significant at $\mathrm{p} \leq 0.05, \mathrm{n}$ : number, $\mathrm{m} / \mathrm{s}$ : meter/ second.

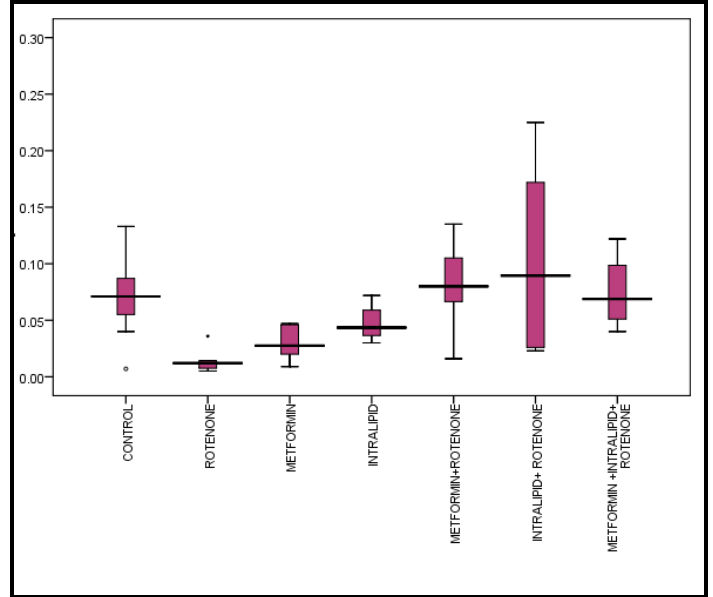

Fig. (1): A diagram showing the mean values of path efficiency in all studied groups.

In the rotenone group, sections stained with H\&E showed severe degenerative changes such as shrunken cytoplasm and extensively dark pyknotic and apoptotic nuclei

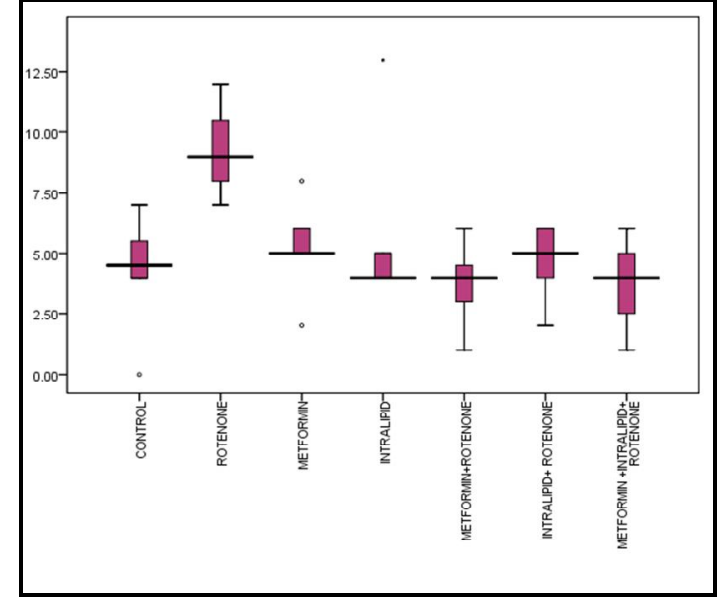

Fig. (2): A diagram showing the mean values of the rotations of the animal's body in all studied groups.

in neurons as well as perineuronal vacuolation. Also, there were leukocytic infiltration, dilated blood vessels, and congested capillaries with red blood cells (Figure 3, G2). 
Metformin improved the pathological effects of rotenone apart from some pyknotic and apoptotic cells (Figure 3, G5). More improvement was seen after intralipid treatment but with some perivascular

vacuolation, pyknotic and apoptotic nuclei in neurons (Figure 3, G6). Sections from mice treated with combined metformin plus intralipid plus rotenone showed almost normal neuronal cells in striatum (Figure 3, G7).
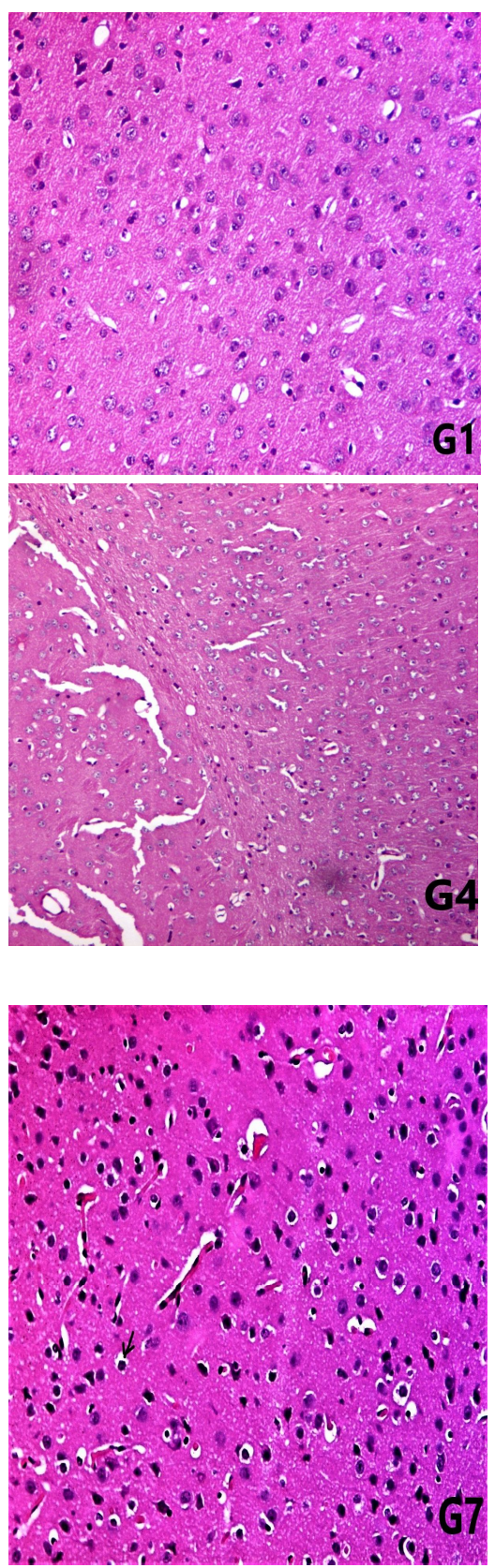
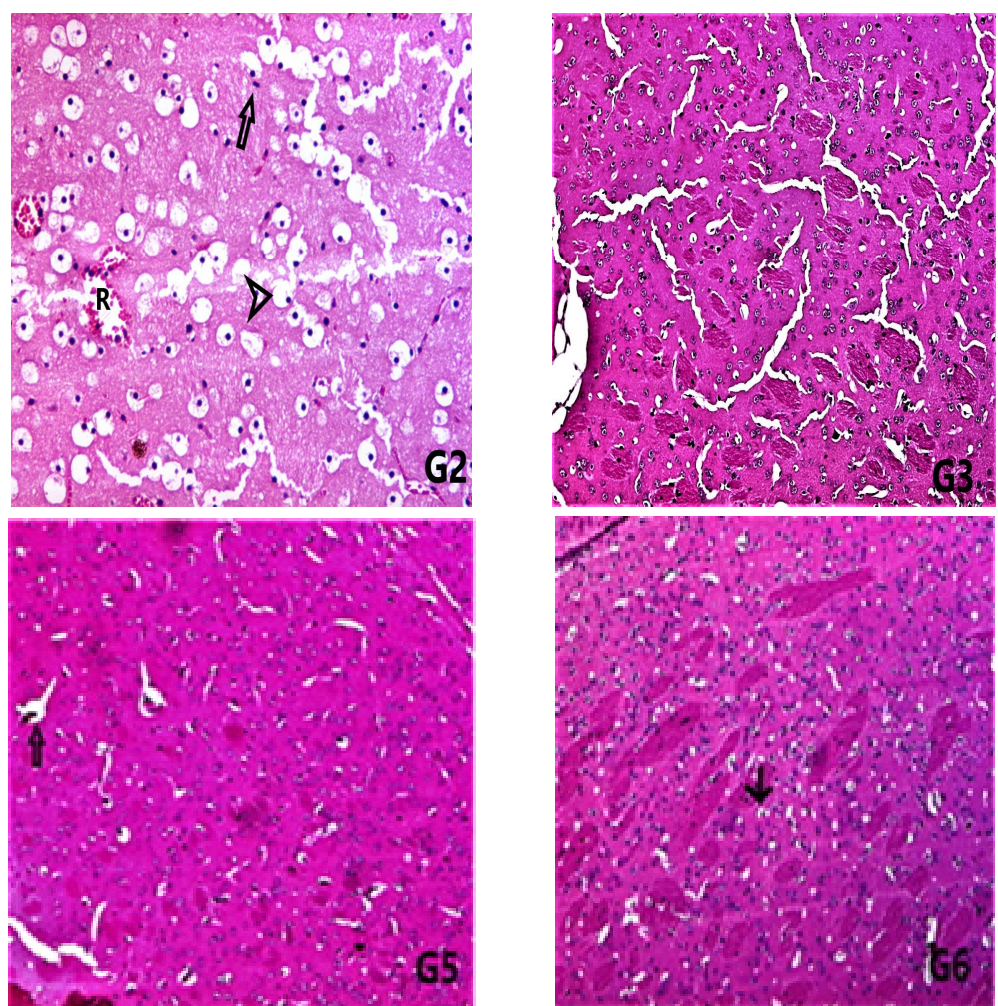

Fig. (3): A microphotograph from sections of the striatum of a mouse G1; from the control group shows normal neurons, G2; rotenone group shows severe degenerative changes as numerous extensively dark pyknotic nuclei (arrow), apoptotic nuclei in neurons (arrowhead) surrounded by perineuronal vacuolation and congested capillaries with RBCs (R), G3; metformin group shows almost normal tissue with normal architecture, G4; intralipid group shows almost normal tissue, G5; metformin-treated group shows some pyknotic and apoptotic cells amidst normal neurons with normal morphology (arrow), G6; intralipid treated group shows some pyknotic and apoptotic cells (arrow), G7; the combined metformin and intralipid treated group shows few pyknotic and apoptotic cells (arrow) surrounded by normal neurons with normal morphology (H\&E X 400). 
Table (3) illustrates the statistical difference between the studied groups as regards the fiber density of the corpus striatum analyzed by Image J. There was a statistically significant distinction between all studied groups compared to the control group. There was additionally a statistically excessive widespread increase in fiber density of corpus striatum in all studied groups in contrast to the rotenone group.

Moreover, no statistically significant difference was found when the intralipid treated group was compared to the metformintreated group. Combined therapy showed a significant increase in fiber density of corpus striatum compared to either metformin or intralipid therapy alone.

Table (3): Statistical analysis between studied groups regarding fiber density of corpus striatum analyzed by image $J(n=70$ mice $)$.

\begin{tabular}{|l|c|c|c|c|c|c|c|}
\hline \multicolumn{1}{|c|}{$\begin{array}{c}\text { Studied groups } \\
\text { (n=10 mice each) }\end{array}$} & $\begin{array}{c}\text { Fiber density of } \\
\text { corpus striatum } \\
\text { mean } \pm \text { SEM }\end{array}$ & p1 & p2 & p3 & p4 & p5 & p6 \\
\hline Control & $200.26 \pm 2.18$ & & & & & & \\
\hline Rotenone & $83.13 \pm 9.51$ & $<0.001^{*}$ & & & & & \\
\hline Metformin & $196.12 \pm 1.35$ & $<0.001^{*}$ & $<0.001^{*}$ & & & & \\
\hline Intralipid & $193.75 \pm 3.95$ & $0.001^{*}$ & $<0.001^{*}$ & 0.130 & & & \\
\hline Metformin + rotenone & $173.75 \pm 2.96$ & $<0.001^{*}$ & $<0.001^{*}$ & $<0.001^{*}$ & $<0.001^{*}$ & & \\
\hline Intralipid + rotenone & $176.75 \pm 3.61$ & $<0.001^{*}$ & $<0.001^{*}$ & $<0.001^{*}$ & $<0.001^{*}$ & 0.091 & \\
\hline $\begin{array}{l}\text { Metformin } \\
\text { intralipid+ rotenone }\end{array}$ & $194.12 \pm 3.90$ & $0.002^{*}$ & $<0.001^{*}$ & 0.193 & 0.851 & $<0.001^{*}$ & $<0.001^{*}$ \\
\hline ANOVA test & \multicolumn{2}{|c|}{$\mathbf{6 3 6 . 7 4}$} & & \\
\hline p-value & &
\end{tabular}

P-value: is for comparison between the groups assessed through ANOVA test, p1: on comparing control group with other groups, p2: on comparing rotenone group with other groups, p3: on comparing metformin group with other groups, p4: on comparing intralipid group with other groups, p5: on comparing the metformin-treated group with other groups, p6: on comparing intralipid treated group with other groups, data expressed as mean \pm standard error of the mean $(\mathrm{SEM}),{ }^{*}$ significant at $\mathrm{p} \leq 0.05, \mathrm{n}$ : number.

Figure (4) demonstrated the immunestaining for $\mathrm{TH}$ showing the changes in the corpus striatum (CS) of the studied groups. Mice exposed to rotenone (R) showed significantly more reduction of fiber density in CS than in the other studied groups. Treatment with metformin against rotenone $(\mathrm{M}+\mathrm{R})$ showed a relatively more increase in the fiber density of CS in comparison to the rotenone group but less than the control group; also the group that treated with intralipid against rotenone $(\mathrm{I}+\mathrm{R})$ showed a relatively more increase in the fiber density of $\mathrm{CS}$ in comparison to rotenone group but less than the control group. The group that was treated with combined metformin and intralipid against rotenone $(\mathrm{M}+\mathrm{I}+\mathrm{R})$ showed also increase in the fiber density of $\mathrm{CS}$ in comparison to the rotenone group and near to the control group. 


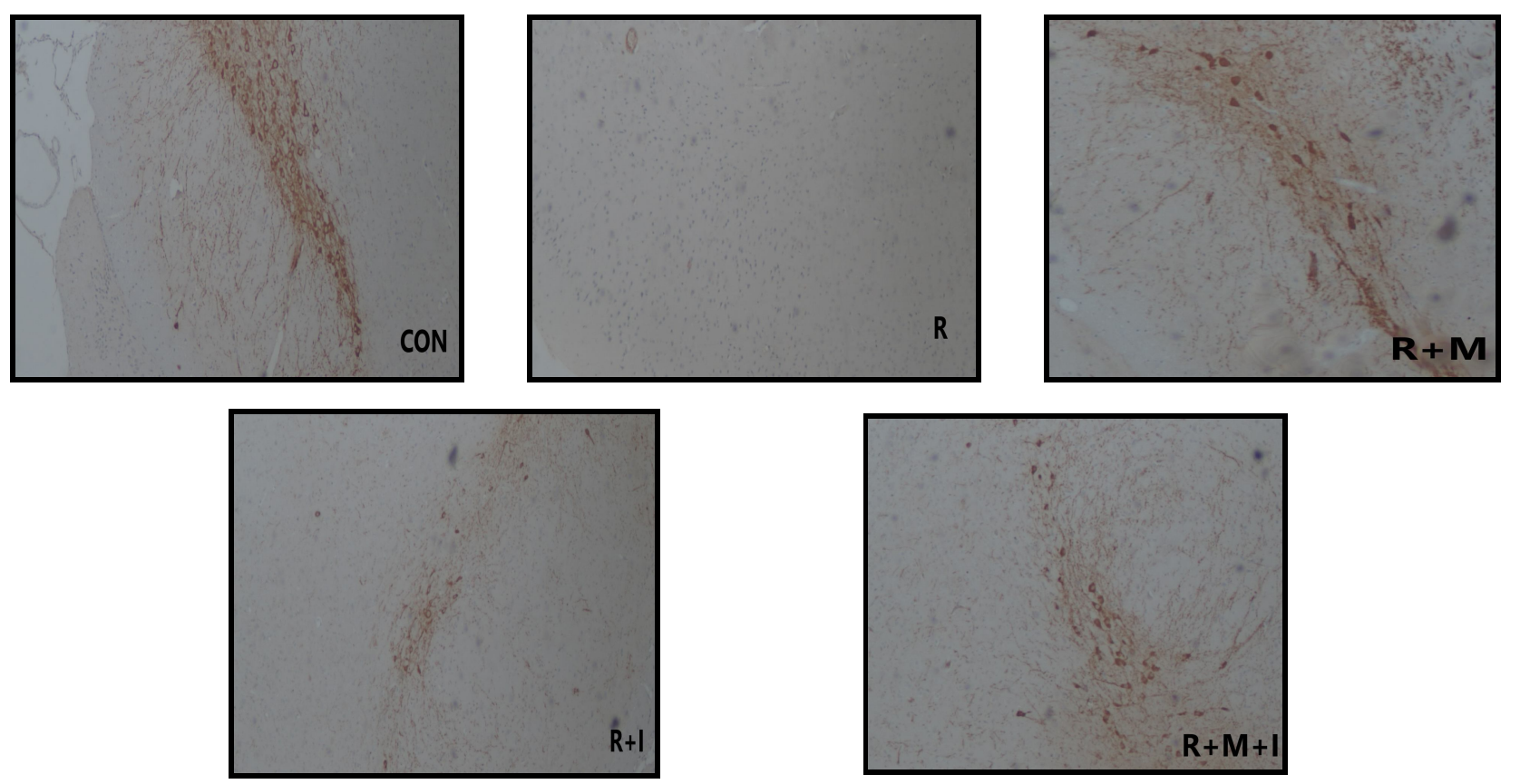

Fig.(4): Tyrosine hydroxylase immunostaining of corpus striatum in all studied groups at $\times 10$ magnification. $\mathrm{CON}$ : control group, $\mathrm{R}$ : rotenone group, $\mathrm{M}+\mathrm{R}$ : metformin and rotenone group, $\mathrm{I}+\mathrm{R}$ : intralipid and rotenone group, $\mathrm{M}+\mathrm{I}+\mathrm{R}$ : metformin and intralipid and rotenone group.

Table (4) illustrates the difference between studied groups as regards the number of light chain 3 (LC3) positive cells, essential for the formation of autophagosomes, quantified by Image $J$.

There was a statistically significant decrease in LC3 positive cells when the rotenone group and metformin-treated group are compared to the control group. However, there was a statistically significant increase in LC3 positive cells in both intralipid treated group and combined metformin and intralipid treated group compared to the rotenone group as well as the control group. However, there was no statistically significant difference between the metformin-treated group and the rotenone group.

Moreover, there was a statistically significant increase in LC3 positive cells was found when intralipid treated group was compared to the metformin-treated group. Also, there was a statistically highly significant increase in LC3 positive cells between the combined metformin and intralipid treated group compared to either the metformin-treated group or the intralipid treated group. 
Table (4): Statistical analysis between the studied groups as regards the number of microtubuleassociated protein light chain 3 (LC3) positive cells for SNPC quantified by image J (according to Kruskal Wallis test) ( $\mathrm{n}=70$ mice).

\begin{tabular}{|l|c|c|c|c|c|c|c|}
\hline \multicolumn{1}{|c|}{$\begin{array}{c}\text { Studied groups } \\
(\mathbf{n}=\mathbf{1 0} \text { mice each) }\end{array}$} & $\begin{array}{c}\text { Number (LC3) } \\
\text { positive cells } \\
\text { median (min- } \\
\text { max) }\end{array}$ & $\mathbf{p 1}$ & $\mathbf{p 2}$ & $\mathbf{p 3}$ & $\mathbf{p 4}$ & $\mathbf{p 5}$ & $\mathbf{p 6}$ \\
\hline Control & $2.00(1.00-4.00)$ & & & & & & \\
\hline Rotenone & $1.00(0.0-3.00)$ & $0.009^{*}$ & & & & & \\
\hline Metformin & $2.00(1.00-4.00)$ & 0.781 & $0.02^{*}$ & & & & \\
\hline Intralipid & $1.50(1.00-3.00)$ & 0.320 & 0.205 & 0.187 & & & \\
\hline Metformin+rotenone & $1.00(.00-2.00)$ & $0.021^{*}$ & 0.725 & $0.008^{*}$ & 0.113 & & \\
\hline Intralipid+ rotenone & $4.00(1.00-6.00)$ & $0.042^{*}$ & $0.002^{*}$ & 0.053 & $0.013^{*}$ & $0.004^{*}$ & \\
\hline $\begin{array}{l}\text { Metformin +intralipid+ } \\
\text { rotenone }\end{array}$ & $6.00(3.00-8.00)$ & $0.001^{*}$ & $0.001^{*}$ & $0.001^{*}$ & $0.001^{*}$ & $0.001^{*}$ & $0.025^{*}$ \\
\hline Kruskil wallis test & $\mathbf{1 6 . 0 3}$ & & & & & \\
\hline p-value & $\mathbf{0 . 0 0 7 *}$
\end{tabular}

P-value: is for comparison between the groups assessed according to the Kruskal Wallis test, $p 1$ : on comparing control group with other groups, $\mathrm{p} 2$ : on comparing rotenone group with other groups, $\mathrm{p} 3$ : on comparing metformin group with other groups, p4: on comparing intralipid group with other groups, p5: on comparing the metformin-treated group with other groups, p6: on comparing intralipid treated group with other groups, data expressed as median (minimum (min)maximum $(\max )\}, *$ significant at $\mathrm{p} \leq 0.05$, n: number, SNPC: substantia nigra pars compacta, LC3: microtubuleassociated protein light chain 3 .

\section{Discussion}

In the present study, when rotenone was given to mice for 4 weeks, it induced definite locomotor changes. These results were similar to previously published research by Zhang et al. (2019). Rotenone given intraperitoneally in two doses ( 1 and $3 \mathrm{mg} / \mathrm{kg} / \mathrm{d}$ ) daily for 21 days, produced a dose-dependent decrease in locomotor activities and a decrease in the number of tyrosine hydroxylase (TH)immunoreactive neurons in the substantia nigra pars compacta (SNpc).

In the present study, intralipid as well as metformin concomitant treatment partially improved the locomotor disturbance induced by rotenone, without significant difference between them. However, their combined administration showed little more improvement than either alone against rotenone effects.
While the present results augmented previously reported improvement by metformin $50 \mathrm{mg} / \mathrm{kg}$ (Afshari et al., 2018), it contradicted Fan and colleagues (2019) who reported that $100 \mathrm{mg} / \mathrm{kg}$ metformin did not improve locomotor activity on anxiety-like actions of rats in the open field test.

In the present study, the therapeutic efficiency of either metformin or intralipid treatment was evident also through improvement in histopathological findings of rotenone. The administration of combined metformin and intralipid exerted more neuroprotective effects against the apoptotic action of rotenone in the mice brain.

These results agreed with previous studies reported by Qin et al. (2015) and Abdel-Salam et al. (2018) who suggested that increased oxidative stress may contribute to rotenone-induced apoptosis. 
The present study examined neurons of the corpus striatum and ventral SNpc region of the midbrain region of mice brain that are involved in the pathology of some neurodegenerative diseases. These cells were more vulnerable to oxidative stress because of their high basal rate of oxygen metabolism and high iron content. Additional oxidative stress from rotenone can easily overload the intrinsic anti-oxidative capacity resulting in neuronal death (Hoffman et al., 2019).

Current results showed that rotenoneinduced significant-high reduction of fiber density in CS. However, either treatment with metformin alone or intralipid alone showed a relative increase in the fiber density of CS in comparison to rotenone group. Combined metformin and intralipid treatment showed more reduction of degenerative effects induced by rotenone.

Rotenone induced reduction of fiber density in CS was well documented (Inden at al., 2011 and Javed et al., 2019) although dose and duration of exposure may differ.

Rotenone exposure was found to cause interference in mitochondrial trafficking that led to the initiation of neurodegenerative mechanisms (Chaves et al., 2013). It also increased the cytoplasmic $\alpha$ synuclein accumulation in surviving dopaminergic neurons (Inden et al., 2011).

Metformine was found to decrease levels of inflammatory cytokines in dopaminergic neurons induced by 1-methyl-4-phenyl-1, 2, 3, 6-tetrahydropyridine (MPTP, an analgesic that produced Parkinson effects) (Lu et al., 2016). In agreement, other investigators found that metformin improves MPTP-induced motoric deficits and decreases MPTP-induced loss of TH-positive neurons in $\mathrm{SN}$ and corpus striatum (Katila et al., 2017). On the other hand, Bayliss et al. (2016) reported that metformin decreased MPTP-mediated loss of TH-positive neuronal cells in corpus striatum but not SN and reduced astrogliosis. On the contrary, Ismaiel and colleagues (2016) reported that metformin had no protective effect against MPTP-induced neuronal loss in the SN.

Other suggested mechanisms of metformin as a neuroprotective agent were that it acts on central metabolism and numerous major signaling pathways including glucose metabolism, the mammalian target of rapamycin (mTOR) signaling, inflammatory signaling as well as induction of autophagy by activation of adenosine monophosphateactivated protein kinase (AMPK). Metformin inhibited complex I of the electron transport chain needed for mitochondrial respiration, thereby leading to an energy deficit and indirectly activating the AMPK pathway (Rotermund et al., 2018).

Previous approaches to protect dopaminergic neurons targeted one of the pathogenic mechanisms affecting these neurons in the course of a disease. So, some trials used antioxidants medications (Pienaar et al., 2009) while, others used anti-inflammatory methods (Kang et al., 2007). Another advocated approach was trying to control cell cycle regulators to discontinue aberrant mitosis (Hoglinger et al., 2007). Selective regulation of microglia in striatal tissues by Lthyroxin was another suggested approach (Salama et al., 2013).

Autophagy was an important cellular response to toxins and oxidative stress. Xiong et al. (2013) demonstrated the involvement of autophagy in rotenone-induced neurotoxic effects both in vitro and in vivo. They suggested that autophagy activation (as a compensatory auto-regulative mechanism) can offer neuroprotection against rotenone-caused neuro-degeneration.

In the current study assessment of autophagy induction was performed by determining Microtubule Associated Protein 
Light Chain 3 (LC3) positive cell expression as a marker for autophagosomes.

The present results showed that rotenone administration decreased significantly the number of LC3 positive cells in the brains of exposed mice i.e. inhibition of autophagy in the dopaminergic system and neurodegeneration. Metformin alone did not induce significant changes in LC3 positive cells compared to the rotenone group and at the same time, that value was significantly low compared to control i.e. less autophagy induction. Interestingly, intralipid therapy induced a significant increase in LC3 positive cells' expression either alone or when combined with metformin. Even it induced more LC3 positive cell expression (more autophagy induction) compared to the control.

In accordance, Xiao et al. (2017) reported that metformin prevented cell death induced by paclitaxel (microtubule inhibiting agent) evidenced by the expression of LC3B. In the same context, Ismaiel and colleagues (2016) reported that metformin reduced microglial activation measured both at the cellular and molecular levels i.e. exacerbated dopaminergic damage rather than protection in response to N-methyl-4-phenyl-1,2,3,6tetrahydropyridine (MPTP). This explained why it is less effective in the protection of brain dopaminergic neurons.

With the increase of lipid emulsion therapy, Sirianni et al. (2008) found that lipid emulsion was efficient for the treatment of toxicity caused by consumed lipophilic drugs. But to the best of our knowledge, this is the first study that investigates the use of intralipid emulsion in the treatment of neurotoxic effects of rotenone.

Heinonen (2016) reported that lipid emulsion causes a significant increase in oxygen flux after the addition of the complex I inhibitor; rotenone. In agreement, Ozkan et al. (2014) found that intralipid decreases the severity of neurodegeneration and symptoms of organophosphate (OP) and organochlorine (OC) intoxication.

Lipid emulsion was also reported to decrease the acute effects of parathion (Dunn et al., 2012) and glyphosate-surfactant herbicide poisoning (Han et al., 2010).

On the other hand, Moshiri et al. (2013) showed that intravenous lipid emulsions $(10 \%$ and $20 \%$ ) failed to either reduce death rate or increase the survival time in acute diazinon (a synthetic organophosphorus) toxicity in comparison with normal saline. This was explained by the conversion of diazinon to a potent and less lipid-soluble agent.

Xiong et al. (2013) demonstrated the protective effects of early-phase activation of autophagy and cell death with late-phase overstimulation of autophagy. Therefore, adequate autophagy regulation instead of extra autophagy enhancement or inhibition should be a therapeutic strategy of neurodegenerative disease management.

From these results, it can be concluded that combined metformin and intralipid therapy improved the neurobehavior, histopathological and immunohistochemical effects of rotenone on the mice. Intralipid therapy was better than metformin in the treatment of rotenone-induced neurotoxicity as evidenced by increase autophagy.

\section{References:}

Abdelrazik, E., El-Bakary, A., Shaaban, S.; et al. (2020): "The role of autophagy in rotenone-induced neurotoxicity in mice". Mansoura Journal of Forensic Medicine and Clinical Toxicology, 28(1): 15-23.
Abdel-Salam,
O.M.E.;
Sleem
A.A.;
Youness, E.R.; et al. (2018):
"Neuroprotection by misoprostol against rotenone-induced neurotoxicity in rat 
brain". Asian Pacific Journal of Tropical Medicine, 11(1): 40-47.

Afshari, K.; Dehdashtian, A.; Haddadi, N.; et al. (2018): "Anti-inflammatory effects of Metformin improve the neuropathic pain and locomotor activity in spinal cord injured rats: introduction of an alternative therapy". Spinal Cord, 56: 1032-1041.

Ahmed, D.; Abdel-Rahman, R.H.; Salama, M.; et al. (2017): "Malathion neurotoxic effects on dopaminergic system in mice". Journal of Biomedical Science, 6(4):130.

Bayliss, J.A.; Lemus, M.B.; Santos, V.V.; et al. (2016): "Metformin prevents nigrostriatal dopamine degeneration independent of AMPK activation in dopamine neurons". PLoS ONE, 11:e0159381. doi: 10.1371/ journal. pone. 0159381 .

Chaves, R.S.; Melo, T.Q.; D'Unhao, A.M.; et al. (2013): "Dynein clhl, dynactin and syntaphilin expression in brain areas related to neurodegenerative diseases following exposure to rotenone". Acta Neurobiologiae Experimentalis (Wars), 73: 541-556.

Cittadini, A.; Napoli, R.; Monti, M.G.; et al. (2012): "Metformin prevents the development of chronic heart failure in the SHHF rat model". Diabetes, 61(4): 944- 953.

Dunn, C.; Bird, S. B. and Gaspari, R. (2012): "Intralipid fat emulsion decreases respiratory failure in a rat model of parathion exposure". Academic Emergency Medicine, 19(5): 504-509.

Eisenkraft, A. and Falk, A. (2016):"The possible role of intravenous lipid emulsion in the treatment of chemical warfare agent poisoning". Toxicology reports, 3: 202-210.
Fan, J.; Li, D.; Chen, H.; et al. (2019): "Metformin produces anxiolytic-like effects in rats by facilitating GABAA receptor trafficking to membrane". British Journal of Pharmacology, 176: 297-316.

Han, S.K.; Jeong, J.; Yeom, S.; et al. (2010): "Use of a lipid emulsion in a patient with refractory hypotension caused by glyphosate-surfactant herbicide". Clinical Toxicology (Phila), 48: 566-568.

Heinonen, J.A. (2016): "Intravenous lipid emulsion for treatment of local anaesthetic and tricyclic antidepressant toxicity". Dissertationes Scholae Doctoralis Ad Sanitatem Investigandam Universitatis Helsinkiensis, 54-62.

Hoffman, G.E.; Murphy, K.J. and Sita, L.V. (2016): "The importance of titrating antibodies for immunocytochemical methods". Current Protocols in Neuroscience, 76: 2.12.1-2.12.37.

Hoffman, M.E.; Augsburger, B.N.; Foradori, C.D.; et al. (2019): "Neuroprotective effects of carnitinoid compounds in rodent cellular and in vivo models of mitochondrial complex I dysfunction". current analysis on biotechnology, 2: 26-33.

Höglinger, G.U.; Breunig, J.J.; Depboylu, C.; et al. (2007): "The $\mathrm{pRb} / \mathrm{E} 2 \mathrm{~F}$ cellcycle pathway mediates cell death in Parkinson's disease". Proceedings of the National Academy of Sciences, 104(9): 3585-3590.

Hu, W.; Tian, H.; Yue, W.; et al. (2016): "Rotenone induces apoptosis in human lung cancer cells by regulating autophagic flux". International Union of Biochemistry and Molecular Biology, 68(5): 388-393.

Inden, M.; Kitamura, Y.; Abe, M.; et al. (2011): "Parkinsonian rotenone mouse model: reevaluation of long-term 
administration of rotenone in $\mathrm{C} 57 \mathrm{BL} / 6$ mice". Biological and Pharmaceutical Bulletin, 34(1): 92-96.

Ismaiel, A.A.; Espinosa-Oliva, A.M.; Santiago, M.; et al. (2016): "Metformin, besides exhibiting strong in vivo antiinflammatory properties, increases mptpinduced damage to the nigrostriatal dopaminergic system". Toxicology and Applied Pharmacology, 298:19-30.

Javed, H.; Azimullah, S.; Abul Khair, S.B.; et al. (2016): "Neuroprotective effect of nerolidol against neuroinflammation and oxidative stress induced by rotenone". BMC neuroscience, 17(1): 58.

Javed, H.; Azimullah, S.; Meeran, M.; et al. (2019): "Neuroprotective effects of thymol, a dietary monoterpene against dopaminergic neurodegeneration in rotenone-induced rat model of Parkinson's Disease". International Journal of Molecular Sciences, 20(7): 1538.

Kang, J.M.; Park, H.J.; Choi, Y.G.; et al. (2007): "Acupuncture inhibits microglial activation and inflammatory events in the MPTP-induced mouse model". Brain Research, 1131: 211-219.

Katila, N.; Bhurtel, S.; Shadfar, S.; et al. (2017): "Metformin lowers alphasynuclein phosphorylation and upregulates neurotrophic factor in the MPTP mouse model of Parkinson's disease". Neuropharmacology, 125: 396407.

Lu, M.; Su, C.; Qiao, C.; et al. (2016): "Metformin prevents dopaminergic neuron death in MPTP/P-induced mouse model of parkinson's disease via autophagy and mitochondrial ROS clearance". The International Journal of Neuropsycho- pharmacology, 19:pyw047. doi: 10.1093/ijnp/pyw047.
Mizushima, N.; Yoshimori, T. and Levine, B. (2010): "Methods in mammalian autophagy research". Cell, 140(3): 313326.

Moshiri, M.; Vahabzadeh, M.; Etemad, L.; et al. (2013): "Failure of intravenous lipid emulsion to reduce diazinoninduced acute toxicity: a pilot study in rats". Iranian Journal of Pharmaceutical Research, 12(4): 897-902.

Netea-Maier, R.T.; Plantinga, T.S.; van de Veerdonk, F.L.; et al. (2016): "Modulation of inflammation by autophagy: consequences for human disease". Autophagy, 12(2): 245-260.

Ozkan, U.; Osun, A.; Basarslan, K.; et al. (2014): "Effects of intralipid and caffeic acid phenethyl ester on neurotoxicity, oxidative stress, and acetylcholinesterase activity in acute chlorpyriphos intoxication". The International Journal of Clinical and Experimental Medicine, 7(4): 837-846.

Pienaar, I.S.; Schallert, T.; Hattingh, S.; et al. (2009): "Behavioral and quantitative mitochondrial proteome analyses of the effects of simvastatin: implications for models of neural degeneration". The Journal of Neural Transmission, 116: 791-806.

Qin, J.; Wu, M.; Yu, S.; et al. (2015): "Pyrroloquinoline quinone-conferred neuroprotection in rotenone models of Parkinson's disease". Toxicology Letters; 238(3): 70-82.

Rotermund, C.; Machetanz, G. and Fitzgerald, J.C. (2018): "The therapeutic potential of metformin in neurodegenerative diseases". Frontiers in Endocrinology, 9(400): 1-26.

Salama, M.; Helmy, B.; El-Gamal, M.; et al. (2013): "Role of 1-thyroxin in counteracting rotenone induced neurotoxicity in rats". Environmental, 
Toxicology and Pharmacology, 35: 270277.

Sirianni, A.J.; Osterhoudt, K.C. and Calello, D.P. (2008): "Use of lipid emulsion in the resuscitation of a patient with prolonged cardiovascular collapse after overdose of bupropion and lamotrigine". The Annals of Emergency Medicine, 51: 412-415.

Swarnkar, S.; Singh, S.; Mathur, R.; et al. (2010): "A study to correlate rotenone induced biochemical changes and cerebral damage in brain areas with neuromuscular coordination in rats". Toxicology, 272: 17-22.

Xiao, Z.; Gaertner, S.; Morresi-Hauf, A.; et al. (2017): "Metformin triggers autophagy to attenuate drug-induced apoptosis in NSCLC Cells, with minor effects on tumors of diabetic patients". Neoplasia, 19(5): 385-395.

Xiong, N.; Xiong, J.; Jia, M.; et al. (2013): "The role of autophagy in Parkinson's disease: rotenone-based modeling". Behavioral and Brain Functions, 9:13.

Zhang, Y.; Guo, H.; Guo, X.; et al. (2019): "Involvement of Akt/mTOR in the neurotoxicity of rotenone-induced parkinson's disease models". The International Journal of Environmental Research and Public Health, 16: 3811.

Zheng, S.; Clabough, E.B.; Sarkar, S.; et al. (2010): "Deletion of the huntingtin polyglutamine stretch enhances neuronal autophagy and longevity in mice". PLoS genetics, 6(2): e1000838. 


\title{
الانتراليبد استراتيجية جديدة كمحفز للالتهام الذاتي ضد التأثيرات السمية العصبية للروتينون
}

\author{
إيمان على عبد الرازق'، آمال عبد السلام البقرى'، سميرة شعبان حامل' ، سارة اللسوقى '، عادل محمود المنصورى'.
}

' قسم الطب الثرعى و السموم الإكلينيكية - كلية الطب - جامعة المنصورة

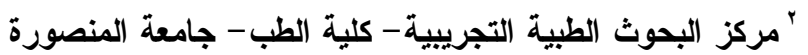

أثبتت الدر اسات السابقة أن تحفيز عملية الالتهام الذاتي قد يكون مفيدًا لعلاج العديد من الأمر اض العصبية

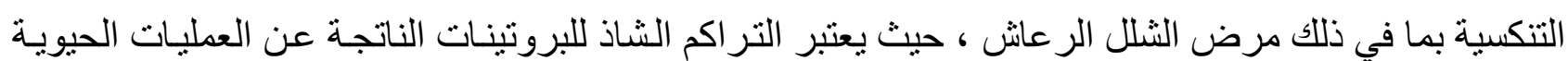
و اختلال وظائف الميتوكوندريا من عو امل ذيادة حدوث الأمر اض العصبية. في الآونة الأخيرة اقترحت عدد من فن فئن الدر اسات أن لمستحلبات الدهون آثار وقائية في العديد من نماذج الأمر اض العصبية التنكسية. ولقد أجريت هذئه الدر اسة لتوضيح دور الانتر اليبد كمثال على مستحلبات الدهون كمحفز للاتهام الذاتي وتقليل حدوث الآثار السمية العصبية للروتينون.

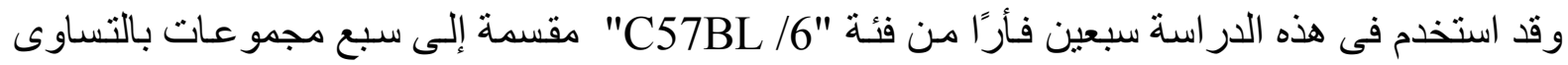

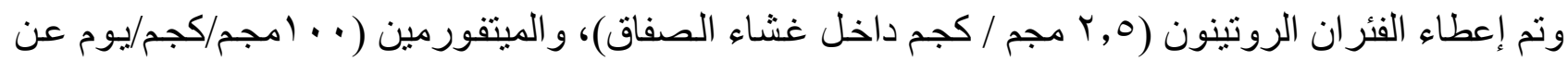

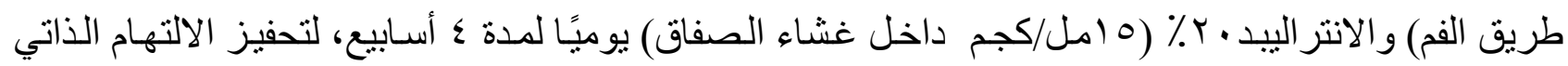

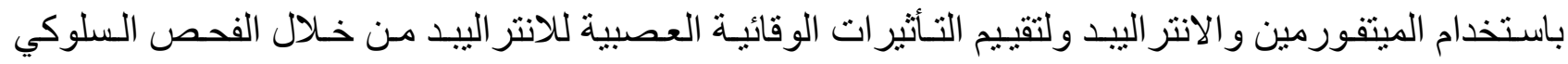
العصبي و الفحص النسيجى و التقييم المنـاعي الكيميائي لـماغ الفئران المعرضـة للرونينون. و قد أظهرت نتائج

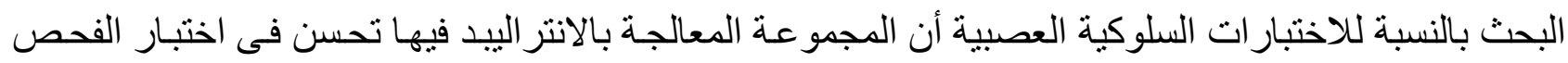
السلوكي العصبي. وقد أظهرت نتائج الفحص النسيجي في المجموعة المعالجة بالانتر اليبد التعافى بشكل ملحوظ بالئ لأنسجة المخ التالفة، وتخفيف تلف الدماغ الناجم عن الروتينون. أمـا التقييم المناعي الكيميائي بصبغة light chain 3 (LC3) antibody (الموجبة فى خلايـا الدوبامين العصبية الموجودة فى المادة السوداء بـالمخ (LC3)

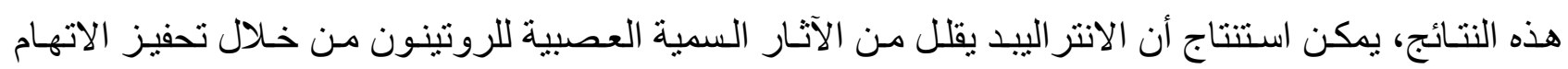
الذاتى. علاوة على ذلك ، أحدث العلاج المشترك للميتفورمين والانتر اليبد ضد الروتينون كفاءة علاجيـة أكثر. قد يمثل الحث الدو ائي للالتهام الذاتي عن طريـق الانتر اليبد استر اتيجية علاجية جديدة للأمـر اض العصبية 